\title{
PENGARUH PENGALAMAN KERJA, INDEPENDENSI, OBJEKTIVITAS, DAN MOTIVASI TERHADAP KUALITAS HASIL PEMERIKSAAN AUDITOR INSPEKTORAT PROVINSI KALIMANTAN TENGAH
}

\author{
Effect of Work Experience, Independence, Objectivity, and Motivation to Results of \\ Auditor's Audit Quality from Inspectorate of Central Kalimantan
}

\author{
*Boby Segah \\ Inspectorate of Central Kalimantan, Yos Soedarso St, Palangka Raya, Indonesia \\ *e-mail : bobisegah22@gmail.com
}

\begin{abstract}
ABSTRAK
Organisasi audit di Indonesia dibagi menjadi dua, yaitu auditor Eksternal Pemerintah yang dilaksanakan oleh Badan Pemeriksa Keuangan (BPK) dan Auditor Internal Pemerintah atau yang lebih dikenal sebagai Aparat Pengawas Intern Pemenrintah (APIP). Fungsi auditor internal adalah melaksanakan fungsi pemeriksaan internal yang merupakan suatu fungsi penilaian yang independen dalam suatu organisasi untuk menguji dan mengevaluasi kegiatan organisasi yang dilakukan. Selain itu, auditor internal diharapkan pula dapat lebih memberikan sumbangan bagi perbaikan efisiensi dan efektivitas dalam rangka peningkatan kinerja organisasi. Salah satu unit yang melakukan audit/pemeriksaan terhadap Pemerintah Daerah adalah Inspektorat Daerah. Auditor Inspektorat Provinsi Kalimantan Tengah hanya melakukan pemeriksaan berupa review Laporan Keuangan Pemerintah Daerah untuk memberikan keyakinan terbatas atas kualitas Laporan Keuangan Daerah bukan berupa pendapat atau opini atas Laporan Keuangan, melainkan hanya rekomendasi. Hal ini tercantum dalam Peraturan Menteri Dalam Negeri Nomor 4 Tahun 2008. Auditor di Inspektorat Provinsi Kalimantan Tengah merupakan auditor internal pemerintah dengan objek pemeriksaan yang sama setiap periode pemeriksaan, maka akan muncul keakraban antara auditor dengan objek pemeriksaan. Keakraban yang muncul dapat menyebabkan independensi auditor terganggu sehingga kualitas hasil pemeriksaannya menurun. Auditor Inspektorat Provinsi Kalimantan Tengah melaksanakan pemeriksaan dilandasi keyakinan bahwa dirinya akan memperoleh kenikmatan pribadi, antara lain berupa kenikmatan meningkatkan kemampuan intelektualitas, kenikmatan meningkatkan atau paling tidak membuka kesempatan pengembangan pribadi serta mempertimbangkan bahwa pemeriksaan merupakan suatu pekerjaan yang menarik dan memberikan tantangan mentalitas profesional.
\end{abstract}

Kata kunci: Pengalaman Kerja, Independensi, Objektivitas, Motivasi, Kualitas Hasil Pemeriksaan

\begin{abstract}
The audit organization in Indonesia is divided into two, namely the Government External auditor conducted by the Supreme Audit Agency (BPK) and the Government Internal Auditor or better known as the Internal Controller of the Government (APIP). The function of the internal auditor is to carry out an internal audit function which is an independent appraisal function within an organization to test and evaluate the organization's activities undertaken. In addition, internal auditors are also expected to contribute more to improving efficiency and effectiveness in order to improve organizational performance. One of the units conducting an audit / examination of the Regional Government is the Regional Inspectorate. The Inspectorate Auditor of Central Kalimantan Province only conducts an examination in the form of a review of the Local Government Financial Statements to provide limited confidence in the quality of the Regional Financial Report not the opinion or opinion on the Financial Statement, but only the recommendation. This is stated in the Minister of Home Affairs Regulation No. 4 of 2008. The Auditor at the Inspectorate of Central Kalimantan Province is a government internal auditor with the same examination object each examination period, it will appear familiarity between the auditor with the object of examination. The emerging familiarity can lead to the independence of the auditor being disrupted so that the quality of the examination results decreases. The Inspectorate Auditor of Central Kalimantan Province conducts an examination based on the belief that he will gain personal pleasure, such as the enjoyment of improving intellectual ability, enhancing pleasure or at least opening personal development opportunities and considering that examination is an exciting job and challenges professional mentality.
\end{abstract}

Keywords: Work Experience, Independence, Objectivity, Motivation, Quality of Examination Results 


\section{PENDAHULUAN}

Peraturan Pemerintah Nomor 79 Tahun 2005 tentang Pedoman Pembinaan dan Pengawasan Penyelenggaraan Pemerintah Daerah menyatakan bahwa pengawasan terhadap urusan pemerintahan di daerah dilaksanakan oleh Aparat Pengawas Intern Pemerintah (APIP) sesuai dengan fungsi dan kewenangannya. Aparat Pengawasan Intern Pemerintah (APIP) terdiri dari Badan Pengawasan Keuangan dan Pembangunan (BPKP), Inspektorat Jenderal Departemen, Unit Pengawasan Lembaga Pemerintahan Non Departemen, Inspektorat Provinsi dan Inspektorat Kabupaten/Kota.

Peraturan Pemerintah Nomor 60 Tahun 2008 tentang Sistem Pengendalian Intern Pemerintah menyatakan bahwa Aparat Pengawas Intern Pemerintah (APIP) melakukan pengawasan intern pemerintah melalui audit, reviu, evaluasi, pemantauan dan kegiatan pengawasan lainnya. Pengendalian adalah mekanisme yang dilakukan oleh eksekutif untuk menjamin bahwa sistem dan kebijakan manajemen dilaksanakan dengan baik sehingga tujuan organisasi dapat tercapai. Sedangkan pemeriksaan (audit) merupakan kegiatan yang dilakukan oleh pihak yang memiliki independensi dan memiliki kompetensi profesional untuk memeriksa apakah hasil kinerja pemerintah telah sesuai dengan standar yang ditetapkan.

Salah satu unit yang melakukan audit/pemeriksaan terhadap Pemerintah Daerah adalah Inspektorat Daerah. Inspektorat Daerah mempunyai tugas menyelenggarakan kegiatan pengawasan umum pemerintah daerah dan tugas lain yang diberikan Kepala Daerah, sehingga dalam tugasnya Inspektorat sama dengan Auditor Internal. Audit Internal adalah audit yang dilakukan oleh unit pemeriksa yang merupakan bagian dari organisasi yang diawasi.

Fungsi auditor internal adalah melaksanakan fungsi pemeriksaan internal yang merupakan suatu fungsi penilaian yang independen dalam suatu organisasi untuk menguji dan mengevaluasi kegiatan organisasi yang dilakukan. Auditor internal diharapkan dapat lebih memberikan sumbangan bagi perbaikan efisiensi dan efektivitas dalam rangka peningkatan organisasi. Dengan demikian Auditor Internal Pemerintah Daerah memegang peran yang sangat penting dalam proses terciptanya akuntabilitas dan transparansi pengelolaan keuangan di daerah. Peran dan fungsi Inspektorat Provinsi, Kabupaten/Kota secara umum diatur dalam pasal 4 Peraturan Menteri Dalam Negeri Nomor 64 Tahun 2007. Dalam pasal tersebut dinyatakan bahwa melaksanakan tugas pengawasan urusan pemerintah, Inspektorat Provinsi, Kabupaten/Kota mempunyai fungsi sebagai berikut : pertama, perencanaan program pengawasan; kedua, perumusan kebijakan dan fasilitasi pengawasan; dan ketiga, pemeriksaan, pengutusan, pengujian, dan penilaian tugas pengawasan.

Inspektorat Provinsi adalah aparat pengawas fungsional yang berada di bawah dan bertanggungjawab kepada Gubernur yang melakukan reviu atas Laporan Keuangan Pemerintah Daerah Provinsi sebelum disampaikan Gubernur kepada Badan Pemeriksa Keuangan (BPK). Inspektorat Kabupaten/Kota adalah aparat pengawas fungsional yang berada di bawah dan bertanggungjawab kepada Bupati/Walikota yang melakukan reviu atas Laporan Keuangan Pemerintah Daerah Kabupaten/Kota sebelum 
disampaikan Bupati/Walikota kepada Badan Pemeriksa Keuangan (BPK).

Dalam menjalankan fungsi pemeriksaan berupa reviu, Inspektorat didukung oleh kinerja auditornya yang memiliki peran penting dalam menjalankan fungsi pemeriksaan internal. Seorang auditor harus dapat menerapkan kemampuan, pengetahuan dan pengalamannya dalam setiap kegiatan pemeriksaan yang dilakukannya agar dapat menghasilkan pemeriksaan yang berkualitas. Auditor disyaratkan memiliki pengalaman kerja yang cukup dalam profesi yang ditekuninya serta dituntut untuk memenuhi kualifikasi teknis dan berpengalaman dalam bidangnya. Pemahaman akan pentingnya pengalaman kerja, independensi, objektivitas dan motivasi bagi terwujudnya hasil pemeriksaan yang berkualitas dalam bentuk laporan hasil pemeriksaan akan mampu memotivasi aparat inspektorat untuk menggunakan dan meningkatkan kompetensi dan independensi yang dimilikinya.

Nirmala (2013) berpendapat bahwa pengalaman kerja merupakan hasil interaksi berulang yang didapat dari pelatihan formal dan informal. Auditor yang mempunyai banyak pengalaman kerja akan mempunyai bahan pertimbangan yang baik dalam proses pengambilan keputusan pemeriksaannya. Tim Penyusun STAN (2007) berpendapat bahwa pengalaman seorang auditor biasanya ditunjukkan oleh lamanya yang bersangkutan berkarier di bidang audit atau investigasi, serta sering bervariasinya melakukan pemeriksaan. Jika auditor senior menugaskan orang yang belum atau kurang berpengalaman, maka orang tersebut harus disupervisi atau dibimbing oleh seniornya yang lebih berpengalaman.
Mulyadi (2002) menyatakan bahwa pengetahuan seorang auditor didapat melalui pendidikan formal, yang diperluas melalui pengalaman-pengalaman dan selanjutnya dilakukan dalam bentuk praktik. Pengalaman merupakan suatu proses pembelajaran dan penambahan perkembangan potensi bertingkahlaku baik dari pendidikan formal maupun non formal. Pengalaman sebagai suatu proses yang membawa seseorang kepada suatu pola tingkah laku yang lebih tinggi. Pengalaman audit mempengaruhi ketepatan penilaian auditor terhadap bukti yang dibutuhkan. Pengalaman juga dapat meningkatkan kemampuan auditor untuk mengolah informasi dan menentukan solusi untuk mengambil tindakan-tindakan yang diperlukan.

Subhan (2011) menyatakan bahwa Pengalaman kerja adalah ukuran lamanya seorang bekerja dalam melaksanakan tugasnya. Semakin banyak macam pekerjaan yang dilakukan seseorang, pengalaman kerjanya akan semakin kaya dan luas, dan memungkinkan peningkatan kinerja. Pengalaman auditor mempengaruhi kemampuan kerja, semakin sering auditor bekerja dan melakukan pekerjaan yang sama, maka auditor yang tidak berpengalaman akan cenderung melakukan kesalahan yang lebih banyak dibandingkan dengan auditor yang berpengalaman.

Carolita (2012) berpendapat bahwa pengalaman kerja sangat diperlukan dalam memenuhi kewajiban seorang auditor terhadap tugasnya untuk memenuhi standar umum audit. Sukriah et al (2009) berpendapat bahwa pengalaman kerja dapat diukur dengan indikator lamanya bekerja sebagai auditor dan banyaknya tugas pemeriksaan yang dilakukan oleh auditor. Indikator lamanya bekerja sebagai auditor dapat dilihat dari apakah 
dari lamanya bekerja sebagai seorang auditor memberikan pengalaman bagi auditor dalam menghadapi objek pemeriksaan, memberikan pertimbangan dalam pengambilan keputusan, dan memberikan rekomendasi. Adapun untuk indikator banyaknya tugas pemeriksaan yang dilakukan oleh auditor dapat dilihat apakah dari banyaknya tugas yang telah dikerjakan memberikan pengalaman untuk belajar dari kegagalan sebelumnya, dan dapat memacu auditor untuk menyelesaikan pekerjaan dengan cepat agar tidak terjadi penumpukan tugas.

Efendhy (2010) berpendapat bahwa independensi merupakan suatu istilah yang sering digunakan oleh profesi auditor. Independensi menghindarkan hubungan yang mungkin mengganggu objektivitas auditor. Independensi bagi seorang auditor artinya tidak mudah dipengaruhi oleh segala sesuatu karena seorang auditor melaksanakan pekerjaan untuk kepentingan umum atau publik. Mulyadi (2002) menyatakan bahwa independensi dapat diartikan sebagai sikap mental yang bebas dari pengaruh, tidak dikendalikan oleh orang lain, dan tidak tergantung pada orang lain. Independensi dapat juga diartikan sebagai kejujuran dalam diri auditor dalam mempertimbangkan fakta dan adanya pertimbangan objektif tidak memihak dalam memutuskan dan menyatakan pendapatnya.

Subhan (2011) berpendapat bahwa auditor yang independen adalah auditor yang tidak memihak atau tidak dapat diduga memihak, sehingga tidak merugikan pihak manapun. Independensi dalam pemeriksaan berarti mengambil sudut pandang yang tidak bias. Selanjutnya persepsi publik mengenai hasil pemeriksaan dapat sangat tergantung pada independensi auditor yang melakukan pemeriksaan. Menurut Junaidi et al (2013) independensi merupakan komponen profesional yang harus dipertahankan oleh auditor profesional. Independensi dalam hal ini, auditor lebih mengutamakan kepentingan publik di atas kepentingan klien atau kepentingan auditor sendiri dalam membuat laporan hasil pemeriksaan. Oleh karena itu keberpihakan auditor dalam hal ini lebih diutamakan pada kepentingan publik.

Agoes dan Ardana (2013) berpendapat independensi menjadi fondasi utama atau batu pijakan dalam struktur etika. Independensi juga menjadi faktor yang sangat menentukan bagi pengembangan dan penerapan prinsip-prinsip fundamental etika dalam menekuni profesi auditor. Auditor yang independen adalah auditor yang tidak memihak atau tidak dapat diduga memihak, sehingga tidak merugikan pihak manapun. Auditor tidak hanya independen dalam fakta (independence in fact) tetapi juga independen dalam penampilan (independence in appearance). Independen dalam fakta (independence in fact) lebih cenderung ditunjukkan oleh sikap mental yang tidak terpengaruh oleh pihak manapun. Auditor tidak hanya independen dalam fakta (independence in fact) tetapi juga independen dalam penampilan (independence in appearance). independen dalam fakta (independence in fact) lebih cenderung ditunjukkan oleh sikap mental yang tidak terpengaruh oleh pihak manapun. Adapun independen dalam penampilan (independence in appearance) ditunjukkan oleh keadaan yang tampak dari luar dan dapat mempengaruhi pendapat orang lain terhadap independen auditor.

Menurut Sukriah et al (2009) independensi dapat diukur dengan indikator independensi penyusunan 
program, independensi pelaksanaan pekerjaan, dan independensi pelaporan. Indikator independensi penyusunan program dapat dilihat dari apakah penyusunan program pemeriksaan yang dilakukan oleh auditor bebas dari campur tangan dan interfensi pimpinan maupun pihak lain yang berkepentingan atas pemeriksaan yang akan dilakukan.

Untuk indikator independensi pelaksanaan pekerjaan dapat dilihat dari apakah pemeriksaan yang dilakukan auditor bebas dari usaha objek pemeriksaan untuk menunjuk atau menentukan kegiatan yang diperiksa, apakah auditor bekerjasama dengan objek pemeriksaan dalam mengumpulkan bukti yang relevan, serta apakah auditor bebas dari kepentingan pribadi maupun pihak lain untuk membatasi segala kegiatan pemeriksaan.

Adapun untuk indikator independensi pelaporan dapat dilihat dari apakah laporan hasil pemeriksaan yang dibuat auditor bebas dari pengaruh pihak lain untuk mempengaruhi faktafakta yang dilaporkan serta pertimbangan terhadap isi laporan pemeriksaan, dan apakah laporan hasil pemeriksaan bebas dari bahasa atau istilah yang menimbulkan multi tafsir.

Objektivitas adalah suatu keyakinan serta kualitas yang memberikan nilai bagi jasa atau pelayanan auditor. Objektivitas merupakan suatu ciri yang membedakan profesi akuntan dengan profesiprofesi yang lain. Prinsip objektivitas menetapkan suatu kewajiban bagi auditor untuk tidak memihak, jujur secara intelektual, dan bebas dari konflik. Seorang akuntan profesional seharusnya tidak boleh membiarkan terjadinya bias, konflikkepentingan atau di bawah pengaruh orang lain, sehingga mengesampingkan pertimbangan bisnis dan profesionalnya.

Pemeriksaan adalah suatu proses sistematik untuk memperoleh dan mengevaluasi bukti secara objektif mengenai pernyataan-pernyataan tentang kegiatan dan kejadian ekonomi dengan tujuan untuk menetapkan tingkat kesesuaian antara pernyataan-pernyataan tersebut dengan kinerja yang telah ditetapkan serta menyampaikan hasilhasilnya kepada pemakai yang berkepentingan. Unsur perilaku yang dapat menunjang objektifitas antara lain dapat diandalkan dan dipercaya; tidak merangkap sebagai panitia tender, kepanitiaan lain dan atau pekerjaan-pekerjaan lain yang merupakan tugas operasional objek yang diperiksa; tidak berangkat tugas dengan niat untuk mencari-cari kesalahan orang lain; dapat mempertahankan kriteria dan kebijakan-kebijakan yang resmi; dalam bertindak maupun mengambil keputusan didasarkan atas pemikiran yang logis.

Objektifitas dapat diukur dengan indikator bebas dari benturan kepentingan dan pengungkapan kondisi sesuai fakta. Indikator bebas dari benturan kepentingan dapat dilihat dari apakah auditor dapat bertindak adil tanpa dipengaruhi oleh pihak lain serta tidak memihak kepada siapapun, apakah auditor menolak menerima tugas jika pada saat bersamaan memiliki hubungan kerjasama dengan objek pemeriksaan, dan apakah auditor dapat diandalkan.

Adapun untuk indikator pengungkapan kondisi sesuai fakta dapat dilihat dari apakah auditor tidak dipengaruhi oleh pandangan subjektif pihak-pihak lain serta menggunakan pikiran yang logis, sehingga auditor dapat mengemukakan pendapat sesuai fakta, apakah auditor dalam melaksanakan tugas tidak mencari-cari kesalahan dari objek 
pemeriksaan dan memperhatikan kriteria dan kebijakan yang resmi.

Motivasi adalah keahlian dalam mengarahkan pegawai dan organisasi agar mau bekerja secara berhasil, sehingga tercapai keinginan para pegawai sekaligus tercapainya tujuan organisasi. Terry (dalam Moekijat, 2002) mendefinisikan motivasi sebagai keinginan di dalam seorang individu yang mendorong ia untuk bertindak atau berperilaku dengan cara tertentu; yang prosesnya mencakup : pengenalan dan penilaian kebutuhan yang belum dipuaskan, penentuan tujuan yang akan memuaskan kebutuhan, dan penentuan tindakan yang diperlukan untuk memuaskan kebutuhan. Dalam konteks organisasi, motivasi adalah pemaduan antara kebutuhan organisasi dengan kebutuhan personil. Hal ini akan mencegah terjadinya ketegangan/konflik sehingga akan membawa pada pencapaian tujuan organisasi secara efektif.

Kualitas auditor merupakan kemampuan profesional individu auditor dalam melakukan pekerjaannya yang dapat mempengaruhi kualitas hasil pemeriksaan. Untuk memastikan agar menghasilkan kualitas hasil pemeriksaan yang baik, auditor dengan kemampuan profesionalnya yang tinggi akan melaksanakan pemeriksaan secara benar dan cenderung menyelesaikan setiap tahapan-tahapan proses pemeriksaan secara lengkap, serta mempertahankan sikap skeptisme dalam mempertimbangkan bukti-bukti pemeriksaan yang kurang memadai yang ditemukan selama proses pemeriksaan.

Kualitas hasil pemeriksaan merupakan sebuah konsep yang kompleks dan sulit dipahami. Semakin bagusnya kualitas hasil pemeriksaan akan ditunjukkan oleh hasil pemeriksaan yang dilakukan oleh auditor. Hasil pemeriksaan berupa temuan audit yang menunjukkan bahwa kemampuan auditor dalam mendeteksi kesalahan yang terdapat dalam laporan keuangan (Ardini, 2010).

Setyaningrum (2012) mendefinisikan kualitas hasil pemeriksaan sebagai probabilitas atau kemungkinan dimana seorang auditor menemukan dan melaporkan tentang adanya suatu pelanggaran dalam sistem akuntansi kliennya. Dimana dalam melaksanakan tugasnya tersebut auditor berpedoman pada standar auditing dan kode etik akuntansi publik yang relevan. Probabilitas untuk menemukan pelanggaran tergantung pada kemampuan teknis auditor dan probabilitas melaporkan pelanggaran tergantung pada independensi auditor. Pemeriksaan yang berkualitas adalah pemeriksaan yang dapat ditindaklanjuti oleh audite. Kualitas ini harus dibangun sejak awal pelaksanaan pemeriksaan hingga pelaporan dan pemberian rekomendasi. Dengan demikian, indikator yang digunakan untuk mengukur kualitas pemeriksaan antara lain kualitas proses, apakah audit dilakukan dengan cermat, sesuai prosedur, sambil terus mempertahankan sikap skeptis (Bajuri, 2012).

Kualitas hasil pemeriksaan adalah pelaporan tentang kelemahan pengendalian intern dan kepatuhan terhadap ketentuan, tanggapan dari pejabat yang bertanggungjawab, merahasiakan pengungkapan informasi yang dilarang, pendistribusian laporan hasil pemeriksaan dan tindak lanjut dari rekomendasi auditor sesuai dengan peraturan perundang-undangan (Batubara, 2008).

Menurut Permenpan RB No. 51 Tahun 2012 tentang Jabatan Fungsional Auditor dan Angka 
Kreditnya, auditor adalah jabatan yang mempunyai ruang lingkup, tugas, tanggungjawab dan wewenang untuk melakukan pengawasan intern pada instansi pemerintah, lembaga dan/atau pihak lain yang didalamnya terdapat kepentingan Negara sesuai dengan peraturan perundang-undangan, yang diduduki oleh Pegawai Negeri Sipil dengan hal dan kewajiban yang diberikan secara penuh oleh pejabat yang berwenang.

Dari pengertian di atas, ruang lingkup kerja auditor meliputi pengawasan intern yang meliputi seluruh aspek pengawasan dan berkedudukan sebagai pelaksana teknis fungsional bidang pengawasan di lingkungan Aparat Pengawasan Intern Pemerintah Tugas pokok auditor adalah melaksanakan kegiatan perencanaan, pengorganisasian, pelaksanaan teknis, pengendalian dan evaluasi pengawasan. Dalam melaksanakan penugasan pengawasan yang meliputi audit, evaluasi, reviu, pemantauan dan kegiatan pengawasan lain seperti konsultasi, sosialisasi, asistensi dalam rangka memberikan keyakinan yang memadai, atas efisiensi dan efektifitas manajemen risiko, pengendalian dan proses tata kelola unit yang diawasi, auditor mempunyai kewenangan untuk:

1. Memperoleh keterangan dan/atau dokumen yang wajib diberikan oleh unit yang diawasi dan pihak yang terkait;

2. Melakukan pemeriksaan di tempat penyimpanan uang dan barang milik Negara, di tempat pelaksanaan kegiatan, pembukuan dan tata usaha keuangan Negara, serta pemeriksaan terhadap perhitunganperhitungan, surat-surat, bukti-bukti, rekening koran, pertanggungjawaban, dan daftar lainnya yang terkait dengan penugasan;
3. Menetapkan jenis dokumen, data serta informasi yang diperlukan dalam penugasan pengawasan;

4. Memeriksa secara fisik setiap asset yang berada dalam pengurusan pejabat instansi yang diawasi; dan

5. Menggunakan tenaga ahli di luar tenaga auditor jika diperlukan.

\section{METODOLOGI}

\section{Variabel Pengalaman Kerja}

Pengalaman kerja merupakan keahlian yang secara eksplisit dapat digunakan untuk melakukan pemeriksaan secara objektif. Pengalaman kerja sebagai keterampilan dari seorang ahli. Ahli didefinisikan sebagai seseorang yang memiliki tingkat keterampilan tertentu atau pengetahuan yang tinggi dalam subyek tertentu yang diperoleh dari pelatihan dan pengalaman. Keahlian sebagai pengetahuan tentang suatu lingkungan tertentu, pemahaman terhadap masalah yang timbul dari lingkungan tersebut, dan keterampilan untuk memecahkan permasalahan tersebut. Keahlian atau pengalaman kerjasebagai seseorang yang memiliki pengetahuan dan keterampilan prosedural yang luas yang ditunjukkan dalam pengalaman audit. Seorang yang berkompeten adalah orang yang dengan keterampilannya mengerjakan pekerjaan dengan mudah, cepat, intuitif dan sangat jarang membuat kesalahan.

\section{Variabel Independensi}

Dalam melaksanakan tugas pemeriksaan seorang auditor harus didukung dengan sikap independen, dimana seorang auditor tidak boleh dipengaruhi oleh pihak lain dan tidak dikendalikan oleh pihak lain. Independensi merupakan sikap auditor yang tidak memihak, tidak mempunyai kepentingan 
pribadi dan tidak mudah dipengaruhi oleh pihakpihak yang berkepentingan dalam memberikan pendapat atau simpulan, sehingga dengan demikian pendapat atau simpulan yang diberikan terebut berdasarkan integritas dan objektivitas yang tinggi. Independensi berpengaruh penting sebagai dasar utama agar auditor dipercaya oleh masyarakat umum. Kualitas hasil pemeriksaan yang tinggi dapat dicapai apabila auditor memiliki sikap independensi yang tidak mudah dipengaruhi.

\section{Variabel Objektivitas}

Dalam laporan hasil pemeriksaan, objektivitas berarti penyajian seluruh laporan harus seimbang dalam isi dan redaksi. Peraturan Menteri Pendayagunaan Aparatur Negara Nomor PER/05/M.PAN/03/2008 tentang Audit Pengawasan Intern Pemerintah (APIP) menyatakan bahwa auditor harus memiliki sikap yang netral dan tidak bisa serta menghindari konflik kepentingan dalam merencanakan, melaksanakan dan melaporkan pekerjaan yang dilakukan. Auditor harus objektif dalam melaksanakan pemeriksaan.

\section{Variabel Motivasi}

Motivasi kerja harus dimiliki oleh setiap individu agar tujuan organisasi dapat tercapai. Pentingnya motivasi karena hal ini dapat menyebabkan, menyalurkan dan mendukung perilaku manusia supaya mau bekerja giat dan antusias untuk mencapai hasil yang optimal antara lain:

1. Mengubah pribadi pegawai;

2. Meningkatkan gairah kerja;

3. Meningkatkan disiplin pegawai;

4. Meningkatkan tanggung jawab pegawai;

5. Mempertinggi moral pegawai;

6. Meningkatkan prestasi kerja;

7. Meningkatkan partisipasi pegawai.

\section{HASIL DAN PEMBAHASAN}

Standar audit menjadi bimbingan dan ukuran kualitas kinerja auditor. Kualitas hasil pemeriksaan sebagai ketaatan terhadap standar profesi dan ikatan kontrak selama melaksanakan audit. Menurut Peraturan Menteri Pendayagunaan Aparatur Negara Nomor PER/02/M.PAN/03/2008 pengukuran kualitas audit atas laporan keuangan, khususnya yang dilakukan oleh APIP wajib menggunakan Standar Pemeriksaan Keuangan Negara (SPKN). Dalam Lampiran 3 Standar Pemeriksaan Keuangan Negara (SPKN) disebutkan bahwa "Besarnya manfaat yang diperoleh dari pekerjaan pemeriksaan tidak terletak pada temuan pemeriksaan yang dilaporkan atau rekomendasi yang dibuat, tetapi terletak pada efektivitas penyelesaian yang ditempuh oleh entitas yang diperiksa".

Manajemen entitas yang diperiksa bertanggungjawab untuk menindaklanjuti rekomendasi serta menciptakan dan memelihara suatu proses dan sistem informasi untuk memantau status tindak lanjut atas rekomendasi pemeriksaan dimaksud. Jika manajemen tidak memiliki cara semacam itu, pemeriksa wajib merekomendasikan agar manajemen memantau status tindak lanjut atas rekomendasi pemeriksa, perhatian secara terus-menerus terhadap temuan pemeriksaan yang material beserta rekomendasinya dapat membantu pemeriksa untuk menjamin terwujudnya manfaat pemeriksaan yang dilakukan.

Dalam standar audit APIP disebutkan bahwa audit harus dilaksanakan oleh orang yang memiliki keahlian dan pelatihan teknis cukup sebagai auditor. Dengan demikian, auditor belum memenuhi persyaratan jika tidak memiliki 
pendidikan dan pengalaman yang memadai dalam bidang audit. Dalam audit pemerintahan, auditor dituntut untuk memiliki dan meningkatkan kemampuan atau keahlian bukan hanya dalam metode dan teknik audit, akan tetapi dalam segala hal yang menyangkut pemerintahan seperti organisasi, fungsi, program dan kegiatan pemerintahan. Pernyataan standar umum pertama dalam Standar Pemeriksaan Keuangan Negara (SPKN) adalah "Pemeriksa secara kolektif harus memiliki kecakapan profesional yang memadai untuk melaksanakan tugas pemeriksaan".

Dengan Pernyataan Standar Pemeriksaan Keuangan Negara ini semua organisasi pemeriksaan bertanggungjawab untuk memastikan bahwa setiap pemeriksaan dilaksanakan oleh para pemeriksa yang secara kolektif memiliki pengetahuan, keahlian dan pengalaman yang dibutuhkan untuk melaksanakan tugas tersebut. Oleh karena itu, organisasi pemeriksa harus memiliki prosedur rekrutmen, pengangkatan, pengembangan berkelanjutan dan evaluasi atas pemeriksaan untuk membantu organisasi pemeriksaan dalam mempertahankan pemeriksa yang memiliki kompetensi yang memadai.

Pemeriksa yang ditugasi untuk melaksanakan pemeriksaan menurut Standar Pemeriksaan harus secara kolektif memiliki :

1. Pengetahuan tentang Standar Pemeriksaan yang dapat diterapkan terhadap jenis pemeriksaan yang ditugaskan serta memiliki latar belakang pendidikan, keahlian dan pengalaman untuk menerapkan pengetahuan tersebut dalam pemeriksaan yang dilaksanakan.
2. Pengetahuan umum tentang lingkungan entitas, program dan kegiatan yang diperiksa (objek pemeriksaan).

Pemeriksa yang melaksanakan pemeriksaan keuangan harus memiliki keahlian di bidang akuntansi dan auditing serta memahami prinsip akuntansi yang berlaku umum yang berkaitan dengan entitas yang diperiksa.

Pengalaman kerja auditor adalah pengetahuan, keahlian dan pengalaman yang dibutuhkan auditor untuk dapat melakukan audit secara objektif, cermat dan seksama. Pengalaman kerja yang diperlukan dalam proses audit tidak hanya berupa penguasaan terhadap standar akuntansi dan auditing, namun juga penguasaan terhadap objek audit.

Selain dua hal di atas, ada tidaknya program atau proses peningkatan keahlian dapat djadikan indikator untuk mengukur tingkat pengalaman kerja auditor. Berdasarkan hasil penelitian yang dilakukan oleh Mabruri, Winarna dan Marlina Safitri menunjukkan bahwa adanya pengaruh positif pengalaman kerja terhadap kualitas hasil pemeriksaan.

Independensi auditor merupakan salah satu faktor yang penting untuk menghasilkan pemeriksaan yang berkualitas. Karena jika auditor kehilangan independensinya, maka laporan hasil pemeriksaan yang dihasilkan tidak sesuai dengan kenyataan yang ada, sehingga tidak dapat digunakan sebagai dasar pengambilan keputusan.

Pernyataan Standar Umum Kedua dalam Standar Pemeriksaan Keuangan Negara (SPKN) adalah "Dalam semua hal yang berkaitan dengan pekerjaan pemeriksaan, organisasi pemeriksa dan pemeriksa harus bebas dalam sikap mental dan penampilan dari gangguan pribadi, ekstern dan 
organisasi yang dapat mempengaruhi independensinya". Dengan pernyataan Standar Umum Kedua ini, organisasi pemeriksaan dan para pemeriksanya bertanggungjawab untuk dapat mempertahankan independensinya sedemikian rupa, sehingga pendapat, simpulan, pertimbangan atau rekomendasi dari hasil pemeriksaan yang dilaksanakan tidak memihak dan dipandang tidak memihak oleh pihak manapun. Dalam Lampiran 2 Standar Pemeriksaan Keuangan Negara (SPKN) disebutkan bahwa "Gangguan pribadi yang disebabkan oleh suatu hubungan dan pandangan pribadi mungkin mengakibatkan pemeriksa membatasi lingkup pertanyaan dan pengungkapan atau melemahkan temuan dalam segala bentuknya". Pemeriksa bertanggungjawab untuk memberitahukan kepada pejabat yang berwenang dalam organisasi pemeriksanya apabila memiliki gangguan pribadi terhadap independensi.

Gangguan pribadi dari pemeriksa secara individu meliputi antara lain :

1. Memiliki hubungan pertalian darah ke atas, ke bawah atau sampai dengan derajat kedua dengan jajaran manajemen entitas atau program yang diperiksa atau sebagai pegawai dari entitas yang diperiksa, dalam posisi yang dapat memberikan pengaruh langsung dan signifikan terhadap entitas atau program yang diperiksa.

2. Memiliki kepentingan keuangan baik secara langsung maupun tidak langsung pada entitas atau program yang diperiksa.

3. Pernah bekerja atau memberikan jasa kepada entitas atau program yang diperiksa dalam kurun dua tahun terakhir.

4. Mempunyai hubungan kerjasama dengan entitas atau program yang diperiksa.
5. Terlibat baik secara langsung maupun tidak langsung dalam kegiatan obyek pemeriksaan, seperti memberikan asistensi, jasa konsultasi, pengembangan sistem, menyusun dan/atau mereviu laporan keuangan entitas atau program yang diperiksa.

6. Adanya prasangka terhadap perorangan, kelompok, organisasi atau tujuan suatu program yang dapat membuat pelaksanaan pemeriksaan pemeriksaan menjadi berat sebelah.

Prinsip objektivitas mensyaratkan agar auditor melaksanakan pemeriksaan dengan jujur dan tidak mengkompromikan kualitasnya. Pusdiklatwas BPKP menyatakan objektivitas sebagai bebasnya seseorang dari pengaruh pandangan subjektif pihak-pihak lain yang berkepentingan, sehingga dapat mengemukakan pendapat sesuai dengan fakta yang ada. Aparat Pengawas Intern Pemerintah (APIP) harus memiliki sikap mental yang objektif, tidak memihak dan menghindari kemungkinan timbulnya pertentangan kepentingan (conflict of interest).

Berdasarkan hasil penelitian yang dilakukan oleh Marlina Safitri menunjukkan adanya pengaruh positif antara objektivitas terhadap kualitas hasil pemeriksaan. Hal ini menunjukkan bahwa semakin tinggi objektivitas seorang auditor maka semakin baik pula kualitas hasil pemeriksaan yang dihasilkan.

Motivasi akan membuat seseorang mempunyai semangat juang tinggi untuk meraih tujuan dan memenuhi standar yang ada. Dengan kata lain, motivasi akan mendorong seseorang, termasuk auditor untuk berprestasi, komitmen terhadap kelompok serta memiliki inisiatif dan optimisme yang tinggi. Respon atau tindak lanjut yang tidak 
tepat terhadap hasil pemeriksaan dan rekomendasi yang dihasilkan akan dapat menurunkan motivasi auditor untuk menjaga kualitas hasil pemeriksaan.

Motivasi auditor melakukan pemeriksaan dapat diuraikan sebagai berikut :

1. Penghargaan Intrinsik

a. Kenikmatan pribadi:

1) Pekerjaan yang menarik;

2) Stimulasi intelektual;

3) Pekerjaan yang menantang (mental);

4) Kesempatan pembangunan dan pengembangan pribadi;

5) Kepuasan pribadi.

b. Kesempatan membantu orang lain:

1) Pelayanan masyarakat;

2) Kesempatan membantu personal klien;

3) Kesempatan bertindak sebagai mentor bagi staf audit.

2. Penghargaan Ekstrinsik

a. Karir:

1) Keamanan/kemapanan kerja yang tinggi;

2) Kesempatan karir jangka panjang yang luas;

3) Peningkatan kompetensi.

b. Status:

1) Pengakuan positif dari masyarakat;

2) Penghormatan dari masyarakat;

3) Prestis atau nama baik;

4) Meningkatkan status sosial.

Penghargaan intrinsik dan ekstrinsik berpengaruh positif terhadap motivasi auditor untuk melaksanakan pekerjaan pemeriksa.

\section{KESIMPULAN}

Penulisan Karya Tulis ini berimplikasi pada auditor Inspektorat Provinsi Kalimantan Tengah. Adapun pengaruh pengalaman kerja, independensi, objektivitas dan motivasi terhadap kualitas hasil pemeriksaan yang dilaksanakan oleh auditor Inspektorat Provinsi Kalimantan Tengah menunjukkan bahwa penguasaan terhadap metode dan teknik pemeriksaan serta segala hal yang menyangkut pemerintahan seperti organisasi, fungsi, program dan kegiatan pelaksanaan pemeriksaan merupakan kebutuhan organisasi Inspektorat Provinsi Kalimantan Tengah, sekaligus kebutuhan personil auditor Inspektorat Provinsi Kalimantan Tengah.

Untuk memenuhi tuntutan akuntabilitas publik dan good governance, diperlukan adanya pemeriksaan. Pemeriksaan (audit) merupakan kegiatan yang dilakukan oleh pihak yang memiliki kompetensi dan independensi untuk memeriksa apakah hasil kinerja pemerintah telah sesuai dengan standar yang ditetapkan.

Auditor adalah jabatan yang mempunyai ruang lingkup, tugas, tanggung jawab dan wewenang untuk melakukan pengawasan intern pada Instansi Pemerintah, Lembaga dan/atau pihak lain yang didalamnya terdapat kepentingan Negara sesuai dengan peraturan perundang-undangan, yang diduduki oleh Pegawai Negeri Sipil dengan hak dan kewajiban yang diberikan secara penuh oleh Pejabat yang berwenang. Inspektorat Provinsi/Kabupaten/Kota merupakan Auditor Internal Pemerintah Daerah yang melakukan fungsi pemeriksaan pada Pemerintah Daerah.

Pada dasarnya untuk mencapai tujuan pemeriksaan dibutuhkan pemeriksa yang memiliki keahlian dan kemampuan teknis, integritas dan objektivitas sehingga hasil kerjanya mendapatkan kepercayaan dari stakeholders. Sebelum dinilaihasil kerjanya, manusia akan dilihat dari 
perilakunya, baik sebagai anggota masyarakat maupun sebagai anggota organisasi. Demikian juga sebagai aparat pengawasan yang mengemban kepercayaan untuk mengawasi jalannya pemerintahan dan pembangunan, seharusnya berperilaku baik sehingga menunjang dalam pelaksanaan tugas yang diembannya. Aturan perilaku pemeriksa bertujuan untuk memastikan faktor manusia sebagai pelaksana pemeriksaan berjalan seiring dengan sistem dan peralatan yang terkait dengan pemeriksaan. Dengan demikian pemeriksa diharapkan mampu mengungkapkan hasil penilaiannya secara objektif.

Perilaku yang dituntut sebagai auditor meliputi tiga hal, yaitu sesuai dengan tuntutan organisasi, dalam berinteraksi dengan sesama pemeriksa, dan interaksi dengan pihak yang diperiksa. Perilaku yang dituntut dari seorang auditor adalah:

1. Mentaati segala peraturan perundangundangan yang berlaku;

2. Melaksanakan tugas dengan penuh pengabdian, sesadaran dan tanggung jawab;

3. Memiliki keahlian yang diperlukan;

4. Berintegritas tinggi dan mempertahankan objektivitasnya;

5. Mampu bekerja sama yang sehat, saling mengingatkan dan membimbing sesama auditor;

6. Menciptakan iklim kerja yang baik dan kerja sama yang sehat dengan auditor.

Pada kenyataannya,berbagai bentuk pertentangan kepentingan bisa saja terjadi antara pemeriksa dengan auditan. Dalam kasus demikian timbul ancaman terhadap independensi, sehingga pemeriksa wajib mengungkap sebab-sebab, kejadian dan sifat pertentangan serta dampaknya terhadap penerimaan penugasan pemeriksa. Pengalaman kerja berpengaruh positif terhadap kualitas hasil pemeriksaan, sehingga semakin baik tingkat pengalaman kerja, maka akan semakin baik kualitas audit yang dilakukan.

Independensi tidak berpengaruh secara signifikan terhadap kualitas hasil pemeriksaan, sehingga independensi yang dimiliki auditor Inspektorat Provinsi Kalimantan Tengah tidak menjamin apakah yang bersangkutan akan melakukan pemeriksaan secara berkualitas.

Auditor Inspektorat Provinsi Kalimantan Tengah hanya melakukan pemeriksaan berupa review Laporan Keuangan Pemerintah Daerah untuk memberikan keyakinan terbatas atas kualitas Laporan Keuangan Daerah bukan berupa pendapat atau opini atas Laporan Keuangan, melainkan hanya rekomendasi. Hal ini tercantum dalam Peraturan Menteri Dalam Negeri Nomor 4 Tahun 2008. Auditor di Inspektorat Provinsi Kalimantan Tengah merupakan auditor internal pemerintah dengan objek pemeriksaan yang sama setiap periode pemeriksaan, maka akan muncul keakraban antara auditor dengan objek pemeriksaan. Keakraban yang muncul dapat menyebabkan independensi auditor terganggu sehingga kualitas hasil pemeriksaannya menurun. Motivasi akan mendorong sesorang, termasuk auditor untuk berprestasi, komitmen terhadap kelompok serta memiliki inisiatif dan optimisme yang tinggi. Motivasi berpengaruh positif terhadap kualitas hasil pemeriksaan, sehingga semakin baik tingkat motivasi, maka akan semakin baik kualitas hasil pemeriksaan yang dilakukannya.

Auditor Inspektorat Provinsi Kalimantan Tengah melaksanakan pemeriksaan dilandasi keyakinan bahwa dirinya akan memperoleh kenikmatan 
pribadi, antara lain berupa kenikmatan meningkatkan kemampuan intelektualitas, kenikmatan meningkatkan atau paling tidak membuka kesempatan pengembangan pribadi serta mempertimbangkan bahwa pemeriksaan merupakan suatu pekerjaan yang menarik dan memberikan tantangan mentalitas profesional.

Penulis menganjurkan agar penentu kebijakan perlu terus menjaga dan meningkatkan pengalaman kerja auditor melalui pemberian pelatihan-pelatihan serta kesempatan untuk mengikuti kursus-kursus atau peningkatan pendidikan profesi.

Tidak hanya itu, penentu kebijakan juga tidak boleh melalaikan motivasi yang dimiliki aparat dalam menjalankan tugas pemeriksaan. Karenanya, pihak penentu kebijakan dalam hal ini atasan perlu mengetahui hal apa saja yang berpotensi menaikkan atau menurunkan motivasi aparat. Pihak penentu kebijakan berusaha untuk menghindari adanya mutasi antar satuan kerja yang menyebabkan aparat yang berpengalaman tergantikan oleh aparat yang tidak berpengalaman. Menghindari pertentangan kepentingan yang terjadi diantara Jabatan Struktural dengan Jabatan Fungsional, dimana kedua jabatan tersebut merupakan personil yang ada di Inspektorat Provinsi Kalimantan Tengah.

\section{DAFTAR PUSTAKA}

Agoes dan Ardana. 2013. Etika Bisnis dan Profesi: Tantangan Membangun Manusia Sutuhnya. Edisi Revisi. Salemba Empat : Jakarta.

Ardini, Lilis. 2010. Pengaruh Kompetensi, Independensi, Akuntabilitas dan Motivasi terhadap Kualitas Audit. Majalah Ekonomi. STIESIA : Surabaya.
BPKP. 1998. Modul Diklat Peningkatan Kemampuan APFP Provinsi di Yogyakarta.

Bajuri, Achmat. 2012. Faktor-faktor yang Berpengaruh terhadap Kualitas Audit Auditor Independen pada Kantor Akuntansi Publik (KAP) di Jawa Tengah. Jurnal Akuntansi. Vol. 3, No. 2. Universitas Stikubank : Semarang.

Batubara, Rizal Iskandar. 2008. Analisis Pengaruh Latar Belakang Pendidikan, Kecakapan Profesional, Pendidikan Berkelanjutan dan Independensi terhadap Kualitas Hasil Pemeriksaan (Studi Empiris pada Badan Pengawasan Kota Medan). Tesis. Sekolah Pascasarjana Universitas Sumatera Utara : Medan.

Carolita, Metha Kartika. 2012. Pengaruh Pengalaman Kerja, Independensi, Objektivitas, Kompetensi dan Komitmen Organisasi terhadap Kualitas Hasil Audit (Studi pada Kantor Akuntan Publik di Semarang). Jurnal. Universitas Diponegoro: Semarang.

Efendy, Muh.Taufik. 2010. Pengaruh Kompetensi, Independensi dan Motivasi Auditor terhadap Kualitas Audit Inspektorat dalam Pengawasan Keuangan Daerah (Studi Empiris pada Pemerintah Kota Gorontalo). Tesis. Magister Sains Akuntansi. Universitas Diponegoro : Semarang.

Junaidi, dkk. 2013. Rotasi Semu dan Tenur Kantor Akuntan Publik (KAP) pada Independensi. Simposium Nasional Akuntani XVI : Manado.

Pusdiklatwas BPKP. 2005. Kode Etik dan Standar Audit. Edisi Keempat. Jakarta.

Pusdiklatwas BPKP. 2009. Gambaran Umum Reviu atas Laporan Keuangan. Edisi Kedua. Jakarta.

Republik Indonesia. 2005. Peraturan Pemerintah Republik Indonesia Nomor 79 Tahun 2005 tentang Pedoman Pembinaan dan Pengawasan Penyelenggaraan Pemerintah Daerah. Jakarta.

Republik Indonesia. 2008. Peraturan Pemerintah Republik Indonesia Nomor 60 Tahun 2008 
tentang Sistem Pengendalian Intern Pemerintah. Jakarta.

Republik Indonesia. 2008. Peraturan Menteri Dalam Negeri Nomor 04 Tahun 2008 tentang Pedoman Pelaksanaan Reviu atas Laporan Keuangan Pemerintah Daerah. Jakarta.

Republik Indonesia. 2008. Peraturan Menteri Pendayagunaan Aparatur Negara Nomor PER/05/M.PAN/03/2008 tentang Standar Audit Aparat Pengawas Intern Pemerintah. Jakarta.

Republik Indonesia. 2009. Peraturan Menteri Pendayagunaan Aparatur Negara Nomor 19 Tahun 2009 tentang Pedoman Kendali Mutu Audit Aparat Pengawas Intern Pemerintah. Jakarta.

Republik Indonesia. 2007. Peraturan Kepala Badan Pemeriksa Keuangan Republik Indonesia Nomor 01 Tahun 2007. Standar Pemeriksaan Keuangan Negara. Jakarta.

Nirmala, Rr Putri Ariska. 2013. Pengaruh Independensi, Pengalaman, Due Profesional Care, Akuntabilitas, Kompleksitas Audit, dan Time Buget Pressure terhadap Kualitas Audit (Studi Empiris pada KAP di Jawa Tengah dan DIY). Jurnal. Universitas Diponegoro : Semarang.

Tim Penyusun STAN. 2007. Dasar-dasar Audit Internal Sektor Publik. Modul Program Pendidikan Non Gelar Auditor Sektor Publik. STAN : Jakarta.

Mabruri dan Wunarna. 2010. Analisis Faktor-faktor yang Mempengaruhi Hasil Audit di Lingkungan Pemerintah Daerah. Simposium Nasional Akuntansi XVI : Purwokerto.

Marlina Safitri. 2014. Faktor-faktor yang Mempengaruhi Kualitas Hasil Pemeriksaan (Studi pada Inspektorat Kabupaten/Kota dan Provinsi di Lampung). Skripsi. Fakultas Ekonomi dan Bisnis. Universitas Lampung : Bandar Lampung.

Moekijat. 2002. Dasar-dasar Motivasi. Pioner Jaya: Jakarta.
Mulyadi. 2002. Auditing. Edisi Ketujuh. Salemba Empat: Jakarta.

Sari dan Laksito. 2010. Pengaruh Pengalaman Kerja, Independensi, Objektifitas, Integritas, Kompetensi dan Etika terhadap Kualitas Audit. Jurnal. Universitas Diponegoro : Semarang.

Setyaningrum, Diyah. 2012. Analisis Faktor-faktor yang Mempengaruhi Kualitas Audit BPK-RI. Simposium Nasional Akuntansi XVI : Banjarmasin.

Subhan. 2011. Analisis Variabel-variabel yang Mempengaruhi Kualitas Hasil Pemeriksaan (Studi pada Inspektorat Kabupaten Pamekasan). Jurnal Ekonomi. Universitas Madura.

Sukriah et al., 2009. Pengaruh Pengalaman Kerja, Independensi, Objektivitas, Integritas dan Kompetensi terhadap Kualitas Hasil Pemeriksaan. Simposium Nasional Akuntansi XVI : Palembang. 